\title{
Uji Aktivitas Antioksidan Fraksi N-Heksana Kulit Buah Naga Merah menggunakan Metode 1,1-Difenil-2-Pikrilhidrazil
}

\author{
Sri Wahdaningsih, Widyo Budilaksono, Andhi Fahrurroji
}

${ }^{1}$ Program Studi Farmasi, Fakultas Kedokteran, Universitas Tanjungpura,

\begin{abstract}
Abstrak
Latar Belakang. Data WHO (World Health Organization) tahun 2011 menunjukkan bahwa berbagai penyakit degeneratif termasuk dalam sepuluh penyebab utama kematian manusia di seluruh dunia. Salah satu pemicu utama penyakit degeneratif adalah radikal bebas. Buah naga merah (Hylocerueus lemairei Britton dan Rose) memiliki potensi untuk dikembangkan sebagai sumber antioksidan. Penelitian ini bertujuan untuk mengukur aktivitas antioksidan alami dari fraksi n-heksana kulit buah naga merah. Metode. Simplisia kulit buah naga merah dimaserasi dengan kloroform. Maserat yang didapat selanjutnya difraksinasi dengan n-heksana. Fraksi nheksana kemudian diskrining fitokimia dan terbukti mengandung flavonoid, alkaloid dan steroid. Dilakukan uji pendahuluan terhadap sampel menggunakan metode Kromatografi Lapis Tipis (KLT), dengan fase gerak berupa campuran n-heksana dan etil asetat (10:1). Hasil. Hasil menunjukkan adanya bercak kuning keputihan dengan latar belakang ungu pada plat KLT silika gel $60 \mathrm{~F}_{254}$ ketika disemprot larutan DPPH 0,2\% dengan nilai Rf sebesar 0,22;0,29;0,36;0,52; 0,67 dan 0,88 . Kesimpulan. Uji aktivitas antioksidan dari fraksi n-heksana kulit buah naga merah dilakukan dengan menggunakan metode DPPH (1,1-difenil-2-pikrilhidrazil), yang diukur dengan menggunakan spektrofotometer UV-Vis pada $\lambda_{\text {maks }} 515,50 \mathrm{~nm}$. Nilai IC $_{50}$ sampel yaitu 206,591 $\mu \mathrm{g} / \mathrm{mL}$ dan tergolong kurang aktif, sedangkan nilai $\mathrm{IC}_{50}$ vitamin $\mathrm{C}$ sebagai kontrol positif jauh lebih kecil, yaitu $2,973 \mu \mathrm{g} / \mathrm{mL}$ dan tergolong sangat kuat.
\end{abstract}

Kata kunci : Antioksidan, Fraksi N-Heksana, Kulit Buah Naga Merah, KLT, DPPH

Background. WHO's (World Health Organization) data in 2011 showed that some degenerative diseases included as the top ten causes of death in the world. The importance substrate that can reduce negative impact of free radicals attack is antioxidant. Red dragon fruit (Hylocerueus lemairei Britton and Rose) has a potential to develope as the source of natural antioxidant. This study aims to determine the antioxidant activity of n-hexane fraction of red dragon fruit peel. Method. Red dragon fruit peel powder macerated within chloroform, and macerate then fractionated with n-hexane. The result of phytochemical screening showed that the $n$-hexane fraction contains flavonoid, alkaloid and steroid. Preliminary test conducted on sample by using Thin Layer Chromatography (TLC) with a mixture mobile phase of $n$-hexane and ethyl acatate $(10: 1)$. Result. The result indicated the presence of whitish yellow spots on a purple background at silica gel $60 \mathrm{~F}_{254}$ when sprayed $0,2 \% \mathrm{DPPH}$ solution, with $\mathrm{Rf}$ values at 0,$22 ; 0,29 ; 0,36 ; 0,52 ; 0,67$ and 0,88 . Conclusion. Antioxidant activity assay of $n$-hexane fraction of red dragon fruit peel performed by using the DPPH (1,1-difenil-2-pikrilhidrazil) method with UV-Vis spectrophotometric measurements at $\lambda_{\max } 515,50 \mathrm{~nm}$, and its showed that sample had $\mathrm{IC}_{50}$ at $206,591 \mu \mathrm{g} / \mathrm{mL}$ and considered as less active antioxidant, whereas vitamin $\mathrm{C}$ had much lower $\mathrm{IC}_{50}$ value $(2,973 \mu \mathrm{g} / \mathrm{mL})$ and considered as very powerfull antioxidant.

Keywords : Antioxidant, N-Hexane Fraction, Red Dragon Fruit Peel, TLC, DPPH

Jurnal Kesehatan Khatulistiwa. Volume 1 Nomor 2. April 2015 


\section{PENDAHULUAN}

Pesatnya perkembangan ilmu pengetahuan dan teknologi mengakibatkan perubahan pola hidup masyarakat yang semakin dinamis. Hal tersebut tentunya tidak terlepas dari berbagai dampak negatif yang tidak diinginkan, diantaranya adalah meningkatnya faktor-faktor resiko penyebab timbulnya penyakit, terutama penyakit degeneratif. Data WHO (World Health Organization) tahun 2011 menunjukkan bahwa beberapa penyakit degeneratif seperti aterosklerosis, stroke, diabetes mellitus dan lainnya termasuk ke dalam sepuluh penyebab utama kematian manusia di seluruh dunia. Salah satu pemicu utama penyakit degeneratif adalah radikal bebas ${ }^{1}$.

$$
\text { Radikal bebas merupakan }
$$
molekul tidak stabil yang memiliki elektron tidak berpasangan pada orbital luarnya sehingga bersifat sangat reaktif. Radikal bebas dalam jumlah kecil digunakan pada respon seluler dan sistem imun. Namun pada konsentrasi yang tinggi radikal bebas dapat menghasilkan stres oksidatif yang menyebabkan kerusakan struktur sel, termasuk kerusakan lipid, protein dan DNA ${ }^{2}$. Substansi penting yang dapat membantu melindungi tubuh dan mengurangi dampak negatif dari serangan radikal bebas adalah antioksidan.

Antioksidan adalah senyawa kimia yang dapat menyumbangkan satu atau lebih elektron kepada radikal bebas, sehingga reaksi radikal bebas tersebut dapat terhambat dan mencegah terbentuknya radikal bebas baru ${ }^{2}$. Berdasarkan sumbernya, Antioksidan dapat dibedakan menjadi antioksidan 
sintetik dan alami. Seiring dengan semakin meningkatnya kekhawatiran masyarakat terhadap efek samping antioksidan sintetik seperti Butil Hidroksi Anisol (BHA) dan Butil Hidroksi Toluen (BHT) yang bersifat karsinogen, mengakibatkan terjadinya kecenderungan peningkatan penggunaan antioksidan alami $^{3}$.

Buah naga merupakan salah satu tanaman yang sangat potensial untuk dikembangkan, salah satunya yaitu sebagai sumber antioksidan alami. Tingkat pemanfaatan dan konsumsi buah naga semakin meningkat, namun umumnya masih sebatas pada pengolahan daging buahnya saja, padahal sebenarnya masih banyak potensi besar yang dimiliki bagian lainnya, salah satunya adalah kulit buah.
Berdasarkan penelitian yang dilakukan oleh Nurliyana dkk. (2010) diketahui bahwa kandungan fenolik total ekstrak etanol kulit buah naga lebih tinggi daripada kandungan fenolik total yang terdapat pada daging buahnya ${ }^{4}$. Selain itu aktivitas antioksidan kulit buah naga $\left(\mathrm{IC}_{50}=\right.$ 0,3 $\mathrm{mg} / \mathrm{mL}$ ) juga lebih tinggi daripada aktivitas antioksidan daging buahnya $\left(\mathrm{IC}_{50}>1 \mathrm{mg} / \mathrm{mL}\right)$. Kulit buah naga merah juga diketahui mengandung pigmen warna betalain, dimana senyawa tersebut memiliki aktivitas antioksidan 5,6. Aktivitas antioksidan kulit buah naga juga diperkuat dengan penelitian oleh Mitasari (2012) yang menyatakan bahwa ekstrak kloroform kulit buah naga merah memiliki aktivitas antioksidan dengan nilai $\mathrm{IC}_{50}$ sebesar $43,836 \mu \mathrm{g} / \mathrm{mL}^{7}$. 
Uji aktivitas antioksidan kulit buah naga merah diketahui masih terbatas pada uji terhadap ekstrak saja. Oleh karena itu perlu dilakukan penelitian lebih lanjut mengenai aktivitas antioksidan pada tingkat fraksi, dalam hal ini yakni fraksi nheksana.

\section{METODE}

\section{Alat dan Bahan}

Alat-alat yang digunakan pada penelitian ini adalah alat-alat gelas (Pyrex), balb, bejana maserasi, cawan krusibel (Pyrex), bejana KLT, corong pisah (Pyrex), lampu UV 366 nm (Merck tipe 1.13203.0001), lemari asam (ESCO model EFH4A1), oven (Modena tipe BO 3633), rotary evaporator (Heodolph tipe Hei-VAP), ayakan effendorf no.20 (pharmalab), spektrofotometer UVVis (Shimadzu tipe 2450), dan timbangan analitik (Precisa tipe XB 4200C dan BEL tipe M254Ai).

Bahan-bahan yang digunakan pada penelitian ini adalah kulit buah naga merah, vitamin C (Kalbe Farma kode bahan No.13AV01100), larutan metanol p.a (Merck kode bahan No.1.06009.2500), larutan kloroform p.a (Merck kode bahan No.1.02445.2500), larutan etil asetat p.a (Merck kode bahan No.1.09623.1000), larutan n-heksana p.a (Merck kode bahan No.1.04367.2500), larutan n-heksana teknis, akuades, larutan $\mathrm{FeCl}_{3} 1 \%$, larutan $\mathrm{NaCl} 10 \%, \quad$ pereaksi Lieberman-Burchad, pereaksi Dragendroff, pereaksi Mayer; serbuk Mg, larutan $\mathrm{H}_{2} \mathrm{SO}_{4} 2 \mathrm{~N}$, larutan $\mathrm{NaOH} 2 \mathrm{~N}$, larutan $\mathrm{HCl} 2 \mathrm{~N}$, lempeng KLT silika gel $60 \quad \mathrm{~F}_{254}$ (Merck kode bahan No.1.05554.0001), dan kristal 1,1- 
difenil-2-pikrilhidrazil (DPPH) p.a (Sigma-Aldrich kode bahan No.D9132-1G).

\section{Preparasi Sampel}

Sampel yang digunakan yaitu

bagian kulit buah naga merah (Hylocereus lemairei Britton dan Rose). Sampel kulit buah naga merah yang diperoleh dari buah naga merah segar disortir basah, kemudian dibersihkan, dirajang, lalu dikeringkan dengan oven pada suhu $40^{\circ} \mathrm{C}$ sampai kering. Setelah itu dilakukan sortasi kering dan dihaluskan dengan cara diblender kemudian diayak dengan ayakan no.20 hingga diperoleh serbuk halus yang homogen.

\section{Ekstraksi dan Fraksinasi}

Sejumlah 503,68 g simplisia kering dimasukkan kedalam bejana maserasi dan ditambahkan pelarut kloroform p.a sampai semua sampel terendam oleh pelarut. Maserasi dilakukan selama 5 hari, setiap 24 jam pelarut diganti dan dilakukan pengadukan tiga kali sehari. Total jumlah pelarut yang digunakan selama proses maserasi adalah 3,5 liter. Hasil maserasi disaring untuk memisahkan filtrat dan residunya. Filtrat yang diperoleh dikumpulkan dan disaring. Kemudian filtrat tersebut dipekatkan menggunakan rotary evaporator vacuum dan waterbath pada suhu $45^{\circ} \mathrm{C}$ hingga pelarut menguap dan menjadi ekstrak kental.

Sejumlah $8,10 \quad \mathrm{~g}$ ekstrak kloroform yang dihasilkan kemudian dimasukkan ke dalam corong pisah, difraksinasi dengan ekstraksi caircair menggunakan pelarut $n$-heksana teknis. Ekstraksi dilakukan replikasi sebanyak dua kali untuk tiap fraksi menggunakan pelarut dengan volume 
masing-masing $81 \mathrm{~mL}(10 \mathrm{x}$ bobot ekstrak (b/v)) untuk sekali penyarian. Hasil fraksinasi dikumpulkan dan dipekatkan dengan waterbath pada suhu $45^{\circ} \mathrm{C}$ hingga diperoleh fraksi kental. Fraksi n-heksana selanjutnya diuji aktivitas antioksidan menggunakan metode DPPH.

\section{Uji Pendahuluan Aktivitas} Antioksidan secara KLT

Uji pendahuluan pada fraksi kloroform kulit buah naga merah sebagai penangkap radikal dilakukan sesuai metode Demirezer dkk. (2001) dengan sedikit modifikasi ${ }^{8}$. Uji pendahuluan diawali dengan mengaktifkan plat Kromatografi Lapis Tipis (KLT) pada oven dengan suhu $105^{\circ} \mathrm{C}$ selama 10 menit. Plat KLT yang digunakan adalah silika gel $60 \mathrm{~F}_{254}$ dengan luas $2 \times 10 \mathrm{~cm}$. Plat KLT yang telah diaktifkan selanjutnya ditotolkan dengan fraksi kloroform kulit buah naga merah dengan konsentrasi $1 \%$ sebanyak 5 $\mu \mathrm{L}$ menggunakan mikropipet $1 \mu \mathrm{L}$, pada jarak 0,5 cm dari bagian bawah. Penotolan sampel pada plat dilakukan secara perlahan dengan volume yang ditotolkan sebanyak 1 $\mu \mathrm{L}$ sebanyak lima kali penotolan. Tiap-tiap penotolan, bercak dibiarkan hingga kering kemudian dielusi dalam chamber pengelusi KLT menggunakan fase gerak n-heksana : etil asetat dengan perbandingan 10 : 1 sebanyak $2 \mathrm{~mL}$. Jarak elusi yang digunakan adalah $9 \mathrm{~cm}$, setelah dikembangkan sampai batas pengembangan, elusi dihentikan dan lempeng diangin-anginkan hingga kering. Lempeng KLT kemudian diamati pada sinar tampak, sinar UV $366 \mathrm{~nm}$, dan disemprotkan dengan larutan DPPH $\quad 0,2 \%$. Bercak 
diperiksa 30 menit setelah pada $\lambda_{\text {maks }} 515,50 \mathrm{~nm}$. Perlakuan penyemprotan. Senyawa aktif yang sama juga dilakukan untuk penangkap radikal bebas akan larutan blanko (larutan DPPH yang menunjukkan bercak berwarna tidak mengandung bahan uji) dan kuning keputihan dengan latar kontrol positif vitamin C dengan belakang ungu.

konsentrasi $2 \mu \mathrm{g} / \mathrm{mL}, 3 \mu \mathrm{g} / \mathrm{mL}, 4$ $\mu \mathrm{g} / \mathrm{mL}, 5 \mu \mathrm{g} / \mathrm{mL}$, dan $6 \mu \mathrm{g} / \mathrm{mL} . \lambda_{\text {maks }}$

Uji Aktivitas Antioksidan Menggunakan Spektrofotometer Uv-Vis

Aktivitas antioksidan fraksi n-heksana ditentukan dengan metode DPPH sesuai yang digunakan oleh Nurliyana dkk. (2010) dengan sedikit modifikasi ${ }^{4}$. Sebanyak $1 \mathrm{~mL}$ fraksi n-heksana dengan konsentrasi 50 $\mu \mathrm{g} / \mathrm{mL}, 75 \mu \mathrm{g} / \mathrm{mL}, 100 \mu \mathrm{g} / \mathrm{mL}, 125$ $\mu \mathrm{g} / \mathrm{mL}$, dan $150 \mu \mathrm{g} / \mathrm{mL}$ ditambahkan ke dalam $2 \mathrm{~mL}$ DPPH $0,1 \mathrm{mM}$. Campuran selanjutnya dikocok dan diinkubasi pada suhu kamar selama 30 menit di ruang gelap. Larutan ini selanjutnya diukur absorbansinya yang digunakan untuk vitamin $\mathrm{C}$ adalah 515,5 $\mathrm{nm}$. Larutan blanko terdiri dari $2 \mathrm{~mL}$ DPPH $0,1 \mathrm{mM}$ dan $1 \mathrm{~mL}$ metanol p.a. Zeroing awal menggunakan metanol p.a $3 \mathrm{~mL}$. Data hasil pengukuran absorbansi dianalisa persentase aktivitas antioksidannya menggunakan persamaan 1.

$\%$ Penghambatan $=\frac{A_{\text {blanko }}-A_{\text {sampel }}}{A_{\text {blanko }}} \times 100 \%$ Keterangan : $A=$ Nilai absorbansi

Nilai $\mathrm{IC}_{50}$ merupakan nilai yang menggambarkan besarnya 
konsentrasi dari ekstrak uji yang Buah naga merah diperoleh dari dapat menangkap radikal bebas Pusat Pelatihan Pertanian dan sebesar 50\% melalui persamaan garis Pedesaan Swadaya (P4S) Alam regresi linier yang menyatakan Cemerlang Sejahtera, Jalan Raya hubungan antara konsentrasi Sui-Kunyit Km. 84,5 Desa Sungai senyawa uji (x) dengan persen Kunyit Laut, Kecamatan Sungai aktivitas penangkap radikal (y). Dari Kunyit, Kabupaten Pontianak, data tersebut akan diperoleh Provinsi Kalimantan Barat. persamaan $\mathrm{y}=\mathrm{bx}+\mathrm{a}$ dengan a Pengambilan sampel dari tempat sebagai intersep, b sebagai slope dan pembudidayaan ini ditujukan agar nilai koefisien regresi linier identitas jenis, lokasi tumbuh, dinyatakan sebagai $r$. Nilai $r$ yang keseragaman umur, serta masa panen baik adalah mendekati -1 atau +1 tanaman dapat diketahui dengan tergantung pada nilai slope yang jelas. diperoleh.

Buah naga yang digunakan dalam penelitian sebanyak $28,29 \mathrm{~kg}$.

\section{HASIL}

\section{Preparasi Sampel}

Sampel yang digunakan dalam penelitian ini adalah bagian kulit buah (perikarp) dari tanaman buah naga merah (Hylocereus lemairei (Hook) Britton dan Rose).
Dari jumlah tersebut diperoleh bobot kulit buah naga merah sebanyak 6,70 $\mathrm{kg}$ atau sebesar $23,683 \%$ dari bobot buah keseluruhan. Kulit buah naga merah yang telah dikumpulkan kemudian diolah menjadi bentuk simplisia melalui beberapa tahap 
pengolahan, yaitu sortasi basah, aktif kemudian terdesak keluar akibat pencucian, pengubahan bentuk, adanya tekanan osmosis didalam dan pengeringan, sortasi kering, dan diluar sel $^{9}$. penyimpanan. Bobot simplisia yang Ekstrak kloroform yang dihasilkan setelah melalui tahapan- didapat setelah proses maserasi tahapan diatas adalah 518,68 gram. adalah sebanyak $8,33 \mathrm{~g}$ atau dengan nilai rendemen sebesar $1,657 \%$ dari

\section{Ekstraksi dan Fraksinasi}

Ekstraksi kulit buah naga merah dilakukan dengan metode maserasi menggunakan pelarut kloroform. Maserasi dipilih karena dapat mengekstrak senyawa dengan baik dan dapat mencegah dekomposisi senyawa yang labil terhadap pemanasan. Prinsip ekstraksi menggunakan maserasi yaitu adanya difusi cairan penyari ke dalam sel tumbuhan yang mengandung senyawa aktif. Difusi tersebut mengakibatkan tekanan osmosis dalam sel menjadi berbeda dengan keadaan diluar. Senyawa jumlah simplisia, dan berwarna coklat tua. Nilai rendemen menunjukkan seberapa besar jumlah kandungan yang dapat terekstraksi oleh pelarut dalam persen (\%). Ekstrak yang diperoleh kemudian dipartisi dengan menggunakan pelarut n-heksana. Senyawa non polar yang berada pada ekstrak kloroform akan terdistribusi dalam pelarut n-heksana. N-Heksana merupakan salah satu pelarut yang baik untuk mengekstraksi senyawasenyawa yang bersifat non-polar karena memiliki beberapa keunggulan, diantaranya adalah 
bersifat stabil, mudah menguap, selektif, serta menghasilkan jumlah kecil lilin, albumin dan zat warna ${ }^{10}$. Prinsip pemisahan pada proses fraksinasi adalah didasarkan pada perbedaan tingkat kepolaran dan perbedaan bobot jenis antara dua fraksi, yakni fraksi yang memiliki bobot jenis lebih besar akan berada pada fase bawah, sedangkan fraksi yang memiliki bobot jenis yang lebih kecil akan berada pada fase atas.

$$
\text { Fraksi n-heksana yang }
$$
diperoleh dalam penelitian ini memiliki bobot 4,32 $\mathrm{g}$ atau memiliki nilai rendemen sebesar 53,333\% dari ekstrak kloroform. Nilai rendemen yang tinggi tersebut menunjukkan bahwa pelarut n-heksana mampu mengekstrak lebih banyak komponen bioaktif dengan sifat kepolaran yang rendah. Hal tersebut disebabkan oleh kuatnya gugus non polar dalam struktur gugus karbon (non polar) nheksana, serta memiliki indeks polaritas yang sangat rendah (0).

Tabel 1. Hasil Proses Maserasi dan Fraksinasi

\begin{tabular}{lccccc} 
& Jumlah & Pelarut & $\begin{array}{c}\text { Jumlah } \\
\text { pelarut }\end{array}$ & Hasil & Rendemen \\
& Sampel & & & \\
\hline Maserasi & $503,68 \mathrm{~g}$ & Kloroform & $3,5 \mathrm{~L}$ & $8,33 \mathrm{~g}$ & $1,654 \%$ \\
& & & & & \\
\hline Fraksinasi & $8,10 \mathrm{~g}$ & N-Heksana & $162 \mathrm{~mL}$ & $4,32 \mathrm{~g}$ & $53,333 \%$ \\
& & & & & \\
\hline
\end{tabular}

\section{Hasil Uji Pendahuluan Aktivitas}

\section{Antioksidan Secara KLT}

Uji pendahuluan aktivitas antioksidan dilakukan sesuai metode Demirezer dkk, (2001) dengan sedikit modifikasi ${ }^{8}$. Uji pendahuluan aktivitas antioksidan dilakukan dengan metode kromatografi lapis tipis (KLT). Fase diam yang digunakan adalah silika gel $60 \mathrm{~F}_{254}$ yang telah diaktifkan pada oven dengan suhu $105^{\circ} \mathrm{C}$ selama 10 menit, sedangkan fase gerak berupa 
campuran n-heksana : etil asetat

(10:1), serta pereaksi DPPH 0,2\%.

Tabel 2. Hasil Skrining Fitokimia Fraksi N-Heksana Kulit Buah Naga

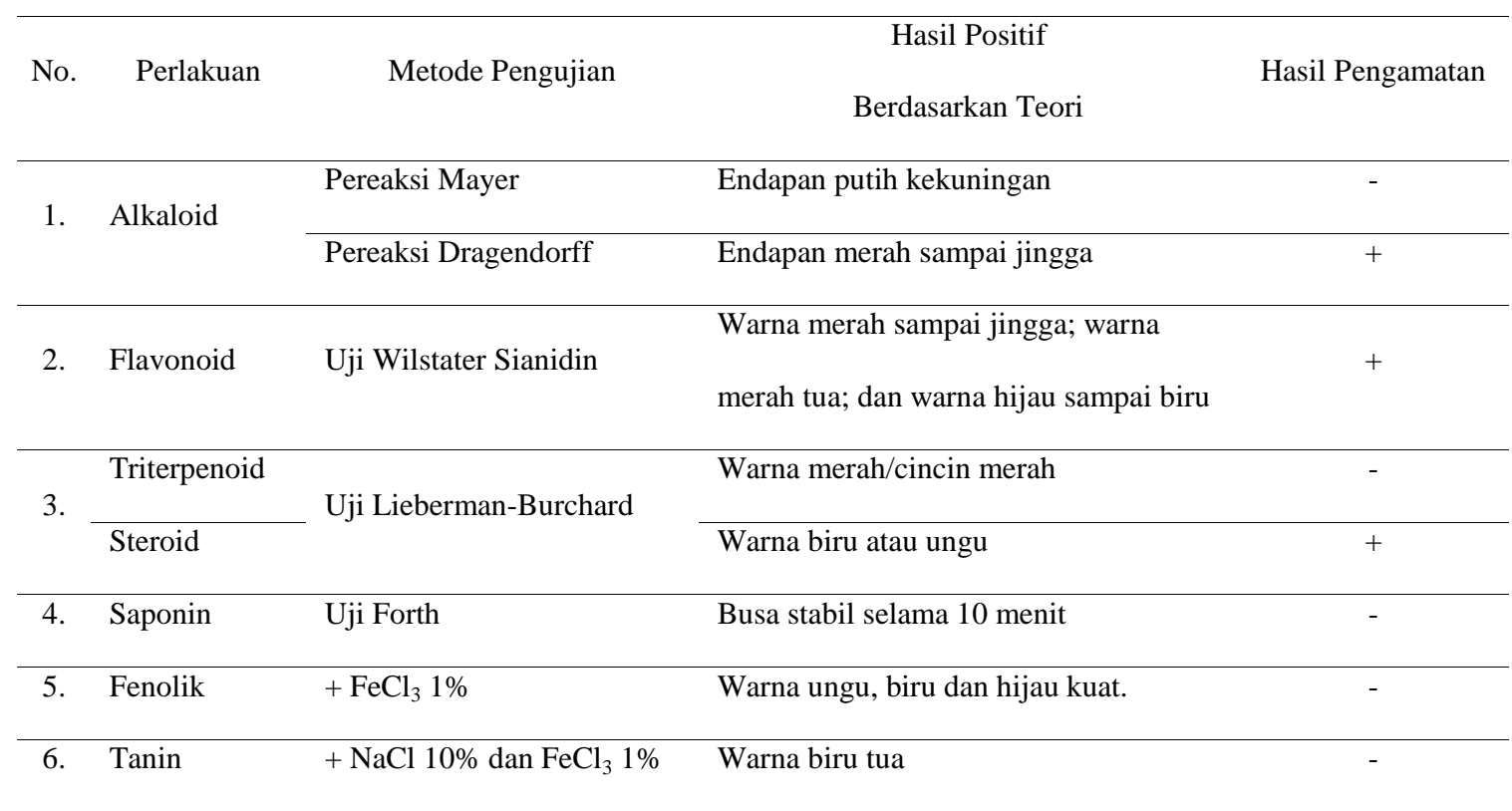

Keterangan: (+) : mengandung senyawa yang diuji; (-) : tidak mengandung senyawa yang duji.

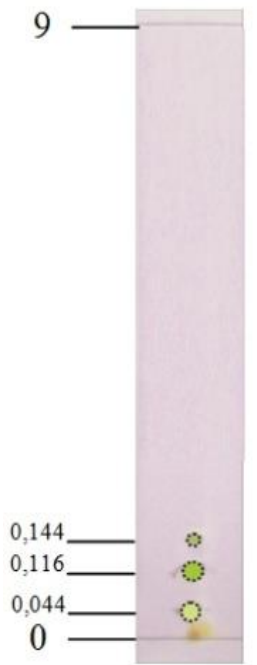

(a)

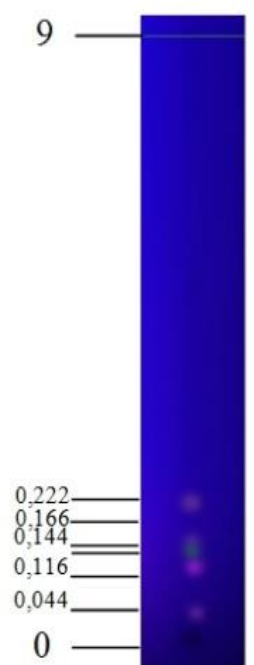

(b)

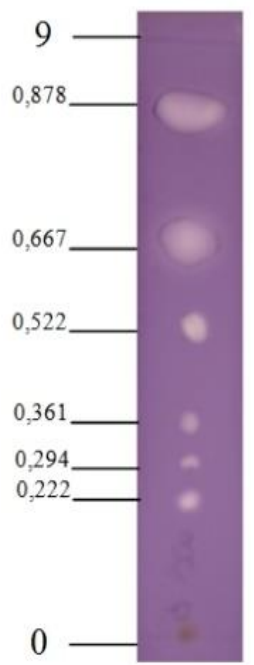

(c)

Gambar 1. Hasil Pemisahan Fraksi N-Heksana Kulit Buah Naga Merah pada Uji Pendahuluan Aktivitas Antioksidan Dengan Fase Diam Silika Gel 60 F $_{254}$, Fase Gerak N-Heksana dan Etil Asetat 10:1. (a). Pengamatan Visual, (b). Dengan Sinar UV 366 nm, (c). dengan Larutan DPPH 0,2\%. 


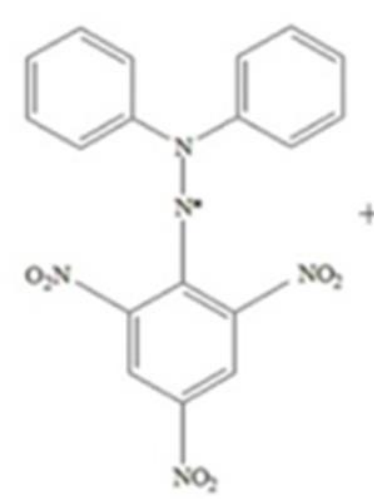

(a)

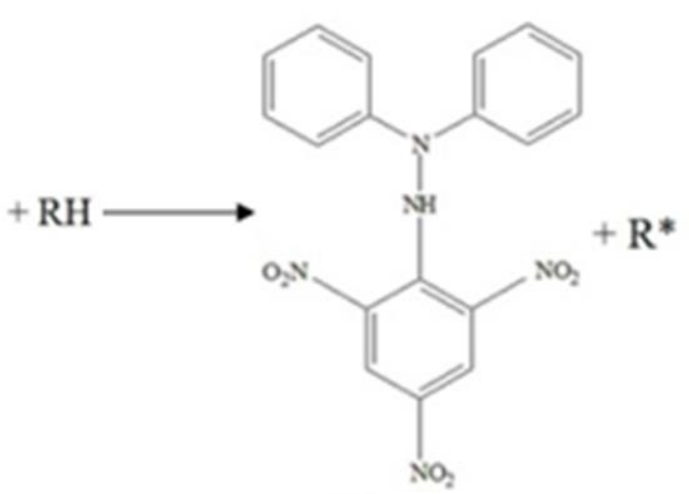

(b)

Gambar 2. Reaksi Reduksi DPPH (1,1-difenil-2-pikrilhidrazil) (a) Menjadi DPPH-H (1,1difenil-2-pikrilhidrazin) (b)

Pemilihan fase gerak tersebut dipilih berdasarkan pada hasil optimasi yang telah dilakukan menggunakan beberapa jenis pelarut organik tunggal maupun campuran.

Berdasarkan hasil pengujian, diperoleh enam bercak yang memberikan hasil uji positif antioksidan dengan menghasilkan bercak kuning keputihan secara spontan dengan latar belakang ungu, yakni dengan nilai Rf 0,$22 ; 0,29$; 0,$36 ; 0,52 ; 0,67$ dan 0,88. Bercak yang menunjukkan hasil positif antioksidan ditandai dengan terbentuknya warna kuning keputih-putihan dengan latar ungu. Hasil kromatogram fraksi n-heksana kulit buah naga merah dapat dilihat pada gambar 1 .

Pada bercak dengan nilai Rf 0,67 dan 0,88 , dihasilkan bercak noda dengan ukuran yang relatif besar, sedangkan pada bercak noda pada $0,22, \quad 0,29 ; \quad 0,36$ dan 0,52 dihasilkan noda dengan ukuran yang lebih kecil. Berdasarkan ukuran noda, dapat diasumsikan bahwa 
semakin besar ukuran noda yang dihasilkan, maka semakin banyak pula jumlah senyawa yang memberikan aktivitas antioksidan. Terbentuknya bercak kuning keputihan spontan setelah penyemprotan $\quad$ DPPH $\quad 0,2 \%$ disebabkan oleh adanya reaksi antara senyawa yang dapat mendonorkan atom hidrogen di dalam ekstrak nheksana kulit buah naga merah dengan molekul DPPH, sehingga mengakibatkan molekul DPPH tereduksi membentuk DPPH-H (1,1difenil-2-pikrilhidrazin) yang diikuti dengan memudarnya warna ungu pada fase diam KLT.

$$
\text { Pengamatan secara visual }
$$
terlihat adanya tiga bercak yang memberikan warna yang berbeda, yakni bercak dengan nilai Rf 0,044 dan memberikan noda berwarna hijau muda yang cukup pudar. Pada bercak kedua dengan nilai $\mathrm{Rf}$ 0,116 dihasilkan noda berwarna hijau dengan intensitas warna yang sedang, dan pada bercak tiga dengan nilai Rf 0,14 dihasilkan bercak dengan warna yang sama dengan bercak kedua, namun dengan ukuran yang lebih kecil. Setelah penyemprotan larutan DPPH $0,2 \%$, ketiga bercak tersebut ternyata tidak memberikan adanya perubahan warna kuning keputihan, hal tersebut dapat diasumsikan bahwa senyawa dalam ketiga bercak tersebut tidak memiliki aktivitas antioksidan. Pengamatan dengan dengan menggunakan sinar UV didapatkan lima bercak noda yang berpendar, yakni pada nilai Rf 0,$04 ; 0,12 ; 0,14$; 0,17 dan 0,22 . Penjang gelombang yang digunakan pada pengamatan ini adalah $366 \mathrm{~nm}$. Pengamatan UV 
dengan menggunakan panjang dengan panjang gelombang 366. Hal gelombang $366 \mathrm{~nm}$ akan ini dapat disebabkan adanya menghasilkan bercak noda yang kemungkinan senyawa tersebut berpendar, dengan latar belakang merupakan senyawa yang dapat yang gelap, sehingga noda yang terdeteksi dengan sinar UV dengan dapat berpendar (berflourosensi) panjang gelombang $254 \mathrm{~nm}$.

dapat terlihat secara visual. Hal Hasil Uji Aktivitas tersebut disebabkan oleh adanya Antioksidan dengan interaksi antara sinar UV dengan Spektrofotometer UV-Visibel gugus kromofor yang terikat oleh Pengukuran aktivitas auksokrom pada bercak noda. antioksidan dengan metode DPPH Fluoresensi cahaya yang tampak menggunakan prinsip merupakan hasil emisi cahaya yang spektrofotometri. Suatu senyawa dipancarkan oleh komponen tersebut yang memiliki aktivitas antioksidan ketika elektron tereksitasi dari akan mendonorkan atom tingkat dasar ke tingkat energi yang hidrogennya untuk berikatan dengan lebih tinggi dan kemudian kembali DPPH membentuk DPPH tereduksi semula sambil melepaskan energi. yang ditandai dengan kehilangan Bercak-bercak noda yang warna ungu menjadi kuning pucat menghasilkan perubahan warna disertai penurunan nilai absorbansi ${ }^{4}$. kuning keputihan yang spontan selain pada $\mathrm{Rf} 0,22$, tidak dapat terdeteksi pada pengamatan UV 
Tabel 3. Hasil Pengukuran yang dilihat dari adanya penurunan

Aktivitas Antioksidan Fraksi N-Heksana

Kulit Buah Naga Merah pada

Spektrofotometri UV-Vis

\begin{tabular}{|c|c|c|c|c|}
\hline $\begin{array}{c}\text { Konsentrasi } \\
(\mu \mathrm{g} / \mathrm{mL})\end{array}$ & Absorbansi & $\begin{array}{l}\text { \% Aktivitas } \\
\text { antioksidan }\end{array}$ & Persamaan Regresi & $\begin{array}{r}\mathrm{IC}_{50} \\
(\mu \mathrm{g} / \mathrm{mL})\end{array}$ \\
\hline Blanko & 1,244 & 0 & \multirow{6}{*}{$\begin{aligned} y & =0,088 x+31,82 \\
r & =0,991\end{aligned}$} & \multirow{6}{*}{206,591} \\
\hline 50 & 0,794 & 36,174 & & \\
\hline 75 & 0,764 & 38,858 & & \\
\hline 100 & 0,748 & 39,871 & & \\
\hline 125 & 0,707 & 43,167 & & \\
\hline 150 & 0,684 & 45,016 & & \\
\hline
\end{tabular}

Pengukuran absorbansi dalam

penelitian ini dilakukan panjang

gelombang maksimum $\left(\lambda_{\text {maks }}\right)$ larutan

DPPH 515,50 nm dengan absorbansi

sebesar 1,244. Kedua panjang

gelombang tersebut sesuai dengan

jangkauan panjang geombang

maksimum yang dapat digunakan

untuk pengukuran dengan metode

DPPH yang dinyatakan oleh

Molyneux (2004), yakni dari $515 \mathrm{~nm}$

sampai dengan $520 \mathrm{~nm}^{11}$.

Data hasil pengukuran pada

tabel 4 menunjukkan adanya

aktivitas peredaman radikal DPPH, nilai absorbansi radikal DPPH yang

disebabkan oleh sampel uji pada

berbagai konsentrasi dan semakin

meningkatnya nilai persen (\%)

aktivitas antioksidan. Hal tersebut

juga terlihat secara kasat mata dengan adanya perubahan warna

ungu yang semakin memudar dan

menjadi agak

kekuningan setelah masa inkubasi 30 menit. Perubahan warna ini terjadi dikarenakan adanya senyawa dalam sampel yang mendonorkan atom hidrogen kepada radikal DPPH sehingga tereduksi menjadi bentuk yang lebih stabil yaitu DPPH-H (1,1-difenil-2pikrilhidrazin) (Gambar 2) ${ }^{12}$. Dari hasil pengukuran fraksi n-heksana kulit buah baga merah menunjukan bahwa semakin tinggi konsentrasi sampel. maka semakin rendah nilai 
absorbansi dari larutan DPPH dalam metanol.

\section{Persamaan regresi antara}

konsentrasi dari fraksi n-heksana kulit buah naga merah (sumbu $\mathrm{x}$ ) dengan persen (\%) aktivitas antioksidan (sumbu y) adalah $\mathrm{y}=$ $0,088 x+31,82$, dengan nilai koefisien korelasi 0,991. Nilai koefisien korelasi yang bernilai positif tersebut menggambarkan bahwa dengan meningkatnya konsentrasi fraksi n-heksana kulit buah naga merah, maka semakin besar pula aktivitas antioksidannya. Hubungan tersebut dapat terlihat pada gambar 3 .

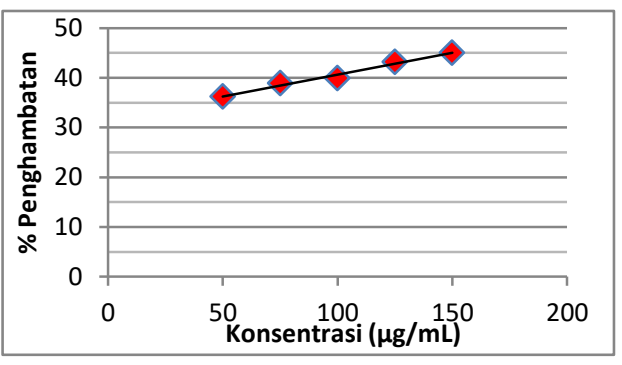

Gambar 3. Kurva Regresi Linier

Pengujian Aktivitas Antioksidan Fraksi

N-Heksana
Parameter yang digunakan dalam pengujian aktivitas antioksidan dengan penangkapan radikal DPPH ini adalah nilai konsentrasi hambatan atau Inhibitory Concentration $\left(\mathrm{IC}_{50}\right)$ atau efficient concentration $\left(\mathrm{EC}_{50}\right)$. Semakin kecil nilai $\mathrm{IC}_{50}$, maka semakin aktif sampel tersebut sebagai antioksidan. Berdasarkan persamaan regresi linear yang diperoleh, nilai $\mathrm{IC}_{50}$ atau konsentrasi yang dibutuhkan untuk menangkap radikal DPPH sebanyak $50 \%$ dari fraksi n-heksana kulit buah naga merah adalah $206,591 \mu \mathrm{g} / \mathrm{mL}$. Nilai ini menyatakan bahwa fraksi nheksana kulit buah naga merah memiliki aktivitas antioksidan yang kurang aktif, namun tetap memiliki potensi antioksidan, karena memiliki nilai $\mathrm{IC}_{50}$ yang berkisar antara 200 $1000 \mu \mathrm{g} / \mathrm{mL}^{11}$. 
Kontrol positif yang dan persen penghambatan vitamin C digunakan dalam penelitian ini dapat terlihat pada gambar 4.

adalah vitamin C. Penggunaan kontrol positif ditujukan untuk membandingkan seberapa kuat potensi antioksidan yang terkandung dalam fraksi n-heksana kulit buah naga merah dengan antioksidan sintetik yang umum digunakan, seperti vitamin $\mathrm{C}$.

Persamaan regresi liner yang didapat dari hasil pengukuran aktivitas antioksidan vitamin $\mathrm{C}$ pada tabel 5 adalah $y=4,397 x+36,929$, dengan nilai koefisien korelasi 0,999. Nilai $\mathrm{IC}_{50}$ yang didapat dari hasil pengukuran vitamin $\mathrm{C}$ adalah sebesar $2,973 \mu \mathrm{g} / \mathrm{mL}$. Nilai ini menunjukkan bahwa vitamin $\mathrm{C}$ memiliki aktivitas antioksidan yang sangat kuat, karena

memiliki nilai $\mathrm{IC}_{50}$ kurang dari 50

$\mu \mathrm{g} / \mathrm{mL}$. Hubungan antara konsentrasi Tabel 4. Hasil Pengukuran Aktivitas Antioksidan Vitamin C pada Spektrofotometri UV-Vis

\begin{tabular}{|c|c|c|c|c|}
\hline $\begin{array}{c}\text { Konsentrasi } \\
(\mu \mathrm{g} / \mathrm{mL})\end{array}$ & Absorbansi & $\begin{array}{l}\text { \% Aktivitas } \\
\text { antioksidan }\end{array}$ & $\begin{array}{c}\text { Persamaan } \\
\text { Regresi }\end{array}$ & $\begin{array}{c}\mathrm{IC}_{50} \\
(\mu \mathrm{g} / \mathrm{mL})\end{array}$ \\
\hline Blanko & 1,244 & 0 & \multirow{6}{*}{$\begin{array}{l}y=4,3847 x+36,929 \\
r=0,9993\end{array}$} & \multirow{6}{*}{2,973} \\
\hline 2 & 0,67089 & 46,070 & & \\
\hline 3 & 0,62459 & 49,792 & & \\
\hline 4 & 0,56728 & 54,399 & & \\
\hline 5 & 0,51212 & 58,833 & & \\
\hline 6 & 0,45439 & 63,473 & & \\
\hline
\end{tabular}

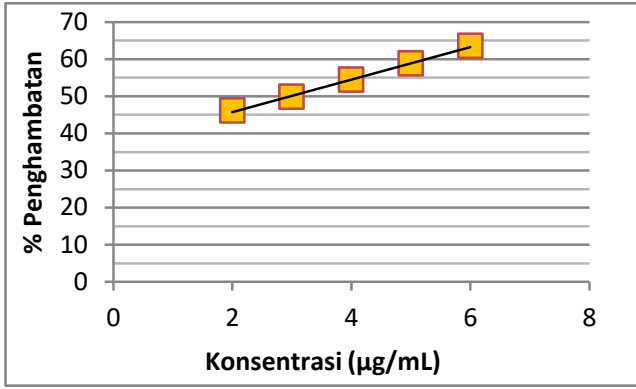

Gambar 4. Kurva Regresi Linier Pengujian Antioksidan Vitamin C

\section{PEMBAHASAN}

Berdasarkan nilai $\mathrm{IC}_{50}$ yang diperoleh antara fraksi n-heksana kulit buah naga merah dan vitamin $\mathrm{C}$

Sebagai kontrol positif, dapat dilihat bahwa nilai $\mathrm{IC}_{50}$ fraksi n-heksana 
kulit buah naga merah jauh lebih besar dibandingkan dengan nilai $\mathrm{IC}_{50}$ vitamin C. Fraksi n-heksana kulit buah naga merah memiliki $\mathrm{IC}_{50}$ sebesar 206,591 $\mu \mathrm{g} / \mathrm{mL} \quad$ dan tergolong kurang aktif, sedangkan vitamin $\mathrm{C}$ memiliki nilai $\mathrm{IC}_{50}$ sebesar $2,973 \mu \mathrm{g} / \mathrm{mL}$ dan tergolong sangat kuat. Hal tersebut menunjukkan fraksi n-heksana kulit buah naga merah memiliki aktivitas antioksidan yang lebih lemah dibandingkan dengan vitamin $\mathrm{C}$. Hal ini diduga disebabkan karena vitamin C merupakan senyawa murni, sedangkan pada fraksi n-heksana kulit buah naga merah masih dalam bentuk fraksi yang masih mengandung berbagai senyawa di dalamnya.

Berdasarkan hasil skrining fitokimia, diduga golongan senyawa yang memberikan aktivitas antioksidan dalam fraksi n-heksana kulit buah naga merah adalah alkaloid, flavonoid dan steroid. Menurut Gusrav (2007), Senyawa flavonoid berperan sebagai antioksidan karena memiliki gugus hidroksil yang dapat melepaskan proton dalam bentuk ion hidrogen. Ion hidrogen hanya memiliki satu buah proton dan tidak memiliki elektron, sehingga dalam elektron radikal yang terdapat pada atom nitrogen di senyawa DPPH berikatan dengan ion hidrogen dan menghasilkan DPPH yang tereduksi 13. Namun flavonoid yang terkandung dalam fraksi n-heksana kulit buah naga merah merupakan senyawa-senyawa yang bersifat nonpolar, yang masih terikat pada gugus glikosidanya sehingga menghambat pengikatan radikal DPPH dan mengakibatkan lemahnya aktivitas 
antioksidan yang dihasilkan. pengganggu seperti protein, lemak Harborne (1987) menyatakan gugus dan senyawa lainnya yang dapat samping yang berikatan dengan terlarut dalam pelarut non-polar, flavonoid dapat mengakibatkan dalam hal ini adalah pelarut $n$ penghambatan aktivitas antioksidan heksana, sehingga menghalangi 14. Hal tersebut mengakibatkan proses penangkapan radikal bebas. flavonoid tidak dapat mendonasikan Adanya senyawa protein atau lemak hidrogen dan elektron untuk pada fraksi dapat mengganggu proses menangkal radikal bebas penangkapan radikal bebas oleh dikarenakan terjadinya halangan senyawa flavonoid. Protein atau sterik. Adanya gugus lain di dalam lemak pada tumbuhan dapat esktrak n-heksana juga dapat memberikan atom hidrogen yang menyebabkan flavonoid termetilasi. dimilikinya sehingga akan berikatan Pengubahan atom -H menjadi gugus dengan radikal hidroksil pada DPPH metil $\left(-\mathrm{CH}_{3}\right)$ melalui reaksi metilasi 16

dapat menurunkan aktivitas

Selain flavonoid, alkaloid antioksidan, yang disebabkan diduga turut bertanggung jawab pengurangan atom $-\mathrm{H}$ yang dalam memberikan aktivitas merupakan sumber proton untuk antioksidan dengan mekanisme penangkapan radikal bebas ${ }^{15}$. sekunder, yakni sebagai penangkap Potensi antioksidan fraksi n- radikal bebas. Hal ini didukung dari heksana yang tergolong kurang aktif penelitian yang telah dilakukan oleh diduga turut disebabkan oleh adanya Maiza-Benabdesselam (2007) 
tentang aktivitas antioksidan dari ekstrak alkaloid dua spesies fumaria (Fumaria capreolata dan Fumaria bastardii), yang menyatakan bahwa aktivitas antioksidan ekstrak alkaloid dari dua spesies Fumaria memiliki aktivitas antioksidan yang bekerja dengan mekanisme sebagai free radical scavenger ${ }^{17}$.

Senyawa steroid dalam fraksi n-heksana kulit buah naga merah diduga turut berperan dalam memberikan aktivitas antioksidan. Mekanisme yang perankan oleh steroid adalah sebagai penangkap radikal. Hal ini didukung berdasarkan penelitian oleh Cui (2003) yang menyatakan bahwa ekstrak etanol $80 \%$ dari inonotus obliquus yang positif mengandung steroid seperti lanosterol dan ergosterol peroksida menghasilkan aktivitas antioksidan sekunder radical scavenger yang cukup aktif 18

$$
\text { Berdasarkan penelitian }
$$
sebelumnya yang telah dilakukan oleh Mitasari (2010) tentang uji aktivitas antioksidan ekstrak kloroform kulit buah naga merah, didapatkan nilai $\mathrm{IC}_{50}$ sebesar 43,8 $\mu \mathrm{g} / \mathrm{mL}$ dan tergolong sangat kuat, sedangkan hasil pengukuran aktivitas antioksidan pada fraksi n-heksana kulit buah naga merah memiliki nilai $\mathrm{IC}_{50}$ yang lebih besar dan tergolong kurang aktif, yakni 206,591 $\mu \mathrm{g} / \mathrm{mL}$. Hal tersebut serupa dengan penelitian yang telah dilakukan oleh Chaman dkk. (2011) yang telah menguji aktivitas antioksidan pada buah beri Sea Buckthorn, dimana ekstrak metanol buah beri Sea Buckthorn memiliki aktivitas antioksidan yang lebih kuat dibandingkan dengan aktivitas antioksidan pada fraksi- 
fraksinya. Hal tersebut disebabkan oleh aktivitas antioksidan dari campuran senyawa yang masih terkandung di dalam ekstrak, sehingga dapat saling berinteraksi dan menghasilkan aktivitas antioksidan yang jauh lebih kuat ${ }^{19}$. Berdasarkan hal tersebut, diduga aktivitas antioksidan yang dihasilkan oleh ekstrak kloroform kulit buah naga merah merupakan hasil dari efek sinergisme antara senyawasenyawa yang terkandung di dialamnya, sehingga setelah dilanjutkan pada tahap fraksinasi, aktivitas antioksidan yang dihasilkan justru semakin kecil.

\section{KESIMPULAN}

Berdasarkan penelitian yang telah dilakukan dapat disimpulkan bahwa fraksi n-heksana kulit buah naga memiliki aktivitas antioksidan yang ditandai dengan timbulnya bercak kuning keputihan spontan saat disemprot larutan DPPH 0,2\% pada uji pendahuluan aktivitas antioksidan secara kromatografi lapis tipis (KLT). Nilai $\mathrm{IC}_{50}$ fraksi n-heksana kulit buah naga merah adalah sebesar 206,591 $\mu \mathrm{g} / \mathrm{mL}$, sedangkan vitamin C sebagai kontrol positif memiliki nilai $\mathrm{IC}_{50}$ sebesar $2,971 \mu \mathrm{g} / \mathrm{mL}$.

\section{DAFTAR PUSTAKA}

1. World Health Organization. 2013. The 10 Leading Causes of Death in The World, 2000 and 2011. (Online) (http://www.who.int/mediacentre/fa ctsheets/fs310/en/index.html, $\quad 7$ Oktober 2013).

2. Winarsi, H., 2007. Antioksidan Alami dan Radikal Bebas.Yogyakarta: Kanisius. Hal: 13; 79-80.

3. Hernani dan Rahardja. 2005. Tanaman Berkhasiat Antioksidan. Jakarta: Penebar Swadaya. Hal: 3-5.

4. Nurliyana, R., Syed Z.I., Mustapha S.K., Aisyah, M.R., dan Kamarul R.K. 2010. Antioxidant study of pulp and peel dragon fruits: a comparative study. Int. Food Res. J. 17: 365-375.

5. Azeredo, H.M.C. 2009. Betalain: Properties, Sources, Applicaions, and Stabily - a Review. Int. J. Food Sci. Technol. 44: 2365-2376.

6. Choo, W.S., dan Yong, W.K., 2011. Antioxidant Properties of Two Species of Hylocereus 
Fruits. Adv. Appl. Sci. Res. 2(3): 418- 425.

7. Mitasari, A. 2012. Uji Aktivitas Ekstrak Kloroform Kulit buah Naga Merah (Hylocereus polyrhizus Britton \& Rose) Menggunakan Metode DPPH (1,1-Defenil-2-Pikril Hidrazil). Skripsi. Pontianak: Program Studi Farmasi, Universitas Tanjungpura. Hal: 37-38.

8. Demirezer, L. O., Kruuzum-Uz, A., Bergere, I., Schiewe, H. J., dan Zeeck, A. 2001. The Structures of Antioxidant and Cytotoxic Agents from Natural Source: Antraquinones and Tannin from Roots of Rumex patientia. Phytochemistry. 58: 1213-1217.

9. Dean, J. 2009. Extraction Techniques In Analytical Science. London: John Wiley And Sons LTD. Hal: 43-46.

10. Guenther, E. 1987. Minyak Atsiri. Diterjemahkan oleh R.S Ketaren dan R. Mulyono. Jakarta: UI Press. Hal: 56.

11. Molyneux, P. 2004. The Use of The Stable Free Radical Diphenylpicrylhydrazyl (DPPH) for Estimating Antioxidant Activity. Songklanakarin J. Sci. Technol. 26(2): 211-219.

12. Rahayu, D.S., Kusrini D., Fachriyah, E. 2010. Penentuan Aktivitas Antioksidan dari Ekstrak Etanol Daun Ketapang (Terminalia catappa L.) dengan Metode 1,1 difenil 2 pikrilhidrazil (DPPH). Skripsi. Semarang : Jurusan Kimia
FMIPA Universitas Dipenogoro. Hal: 77-79.

13. Gurav, S., Deshkar, N., Gulkari, V., Duragkar, N., dan Patil, A., 2007, Free Radical Scavenging Activity of Polygala chinensis Linn, Pharmacologyonline. 2: 245-253.

14. Harborne, J.B. 1987. Metode Fitokimia. Bandung: Penerbit ITB. Hal: 7-8; 49.

15. Mikamo, E., Okada, Y., Semma, M., Itto, Y., dan Morimoto T. 2000. Studies on Structural Correlationship with Antioxidant Activity of Flavonoids. J. Jpn. Soc. Food Sci. Technol. 7: 97-101.

16. Pine, H.S. 1988. Radikal Bebas. Bandung: ITB. Terjemahan dari: Organic Chemistry 2. Hal: 23-26.

17. Maiza-Benabdesselam, F., Khentache, S., Bougoffa, K., Chibane, M., Adach, S., Chapeleur, Y., Max, H. 2007. Antioxidant activities of alkaloid extract of two algerian species of Fumaria: Fumaria capreolata and Fumaria bastardii. Record. Nat. Prod. 1: 2835.

18. Cui, Y., Kim, D.S., dan Park, K.C. 2004. Antioxidant Effect Inonotus Obliquus. J Etnopharmacol. 96: 7985.

19. Chaman, S., Syed, N.I.H., Danish, Z., dan Khan, F.A. 2011. Phytochemical Analysis, Antioxidant and Antibacterial Effects of Sea Buckthorn Berries. Pak. J. Pharm. Sci. 24: 345-351. 